\title{
Rhodococcus yunnanensis sp. nov., a mesophilic actinobacterium isolated from forest soil
}

Correspondence

Wen-Jun Li

wjli@ynu.edu.cn or

lihxu@ynu.edu.cn

\section{Yu-Oin Zhang, ${ }^{1} \dagger$ Wen-Jun Li ${ }^{1} \dagger$ Reiner M. Kroppenstedt, ${ }^{2}$ Chang-Jin Kim, ${ }^{3}$ Guo-Zhong Chen, ${ }^{1}$ Dong-Jin Park, ${ }^{3}$ Li-Hua $\mathrm{Xu}^{1}$ and Cheng-Lin Jiang ${ }^{1}$}

${ }^{1}$ The Key Laboratory for Microbial Resources of Ministry of Education, Yunnan Institute of Microbiology, Yunnan University, Kunming, Yunnan 650091, P. R. China

${ }^{2} \mathrm{DSMZ}$ - Deutsche Sammlung von Mikroorganismen und Zellkulturen GmbH, Mascheroder Weg 1b, D-38124 Braunschweig, Germany

${ }^{3}$ Korea Research Institute of Bioscience and Biotechnology, 52 Oeundong, Yusong, Daejeon 305-333, Republic of Korea

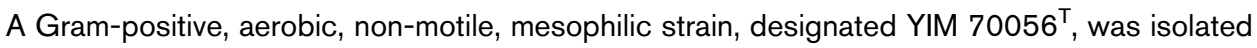
from a forest soil sample in Yunnan Province, China. Phylogenetic analysis based on 16S rRNA gene sequences revealed that this isolate had less than $97 \cdot 0 \%$ similarity to any Rhodococcus species with validly published names, with the exception of Rhodococcus fascians (DSM $20669^{\top}$ ), which was found to be its closest neighbour (98.9 \% similarity). Chemotaxonomic data, including peptidoglycan type, diagnostic sugar compositions, fatty acid profiles, menaquinones, polar lipids and mycolic acids, were determined for this isolate; the results supported the affiliation of strain YIM $70056^{\top}$ to the genus Rhodococcus. The DNA G +C content was $63.5 \mathrm{~mol} \%$. The results of DNA-DNA hybridization with $R$. fascians DSM $20669^{\top}$, in combination with chemotaxonomic and physiological data, demonstrated that isolate YIM $70056^{\top}$ represents a novel Rhodococcus species, for which the name Rhodococcus yunnanensis sp. nov. is proposed,

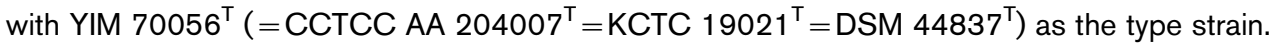

Since the generic name Rhodococcus was first proposed by Zopf (1891), this genus has undergone numerous changes (Goodfellow et al., 1998). The emergence of molecular systematics and numerical phenetic taxonomy has been instrumental in the assignment of species of the genus Rhodococcus to the following four 16S rDNA subclades: Rhodococcus equi, Rhodococcus rhodnii, Rhodococcus rhodochrous and Rhodococcus erythropolis (McMinn et al., 2000).

During the study of the microbial flora of Yunnan Province in south-west China, several Rhodococcus-like actinobacteria strains were isolated and identified from forest soil samples. On the basis of partial $16 \mathrm{~S}$ rRNA gene sequence data, most of these isolates, with the exception of strain YIM $70056^{\mathrm{T}}$, had $98 \cdot 0-99 \cdot 0 \%$ similarity to Rhodococcus species with validly published names. Further study of strain YIM

Published online ahead of print on 16 December 2004 as DOI 10.1099/ijs.0.63390-0.

†These authors contributed equally to this work.

The GenBank/EMBL/DDBJ accession number for the $16 \mathrm{~S}$ rRNA gene sequence of strain YIM $70056^{\top}$ is AY602219.

An extended phylogenetic tree showing the phylogenetic relationships between strain YIM $70056^{\top}$ and related strains is available as a supplementary figure in IJSEM Online.
$70056^{\mathrm{T}}$, based on a polyphasic approach including analysis of complete 16S rRNA gene sequences, DNA-DNA hybridization, morphological observation and physiological and chemotaxonomic analysis, showed that this isolate represents a novel species of the genus Rhodococcus, for which the name Rhodococcus yunnanensis sp. nov. is proposed.

Strain YIM $70056^{\mathrm{T}}$ was isolated on glycerol/asparagine agar (ISP5 medium; Shirling \& Gottlieb, 1966) medium at $28^{\circ} \mathrm{C}$. Good growth was recorded for YIM $70056^{\mathrm{T}}$ on almost all of the tested media, such as ISP2 (Shirling \& Gottleib, 1966), trypticase soy agar (TSA; Difco) and peptone/yeast extract/ glucose medium (Holdeman et al., 1977). The strain was maintained on ISP5 and TSA agar slants at $4{ }^{\circ} \mathrm{C}$ and as glycerol suspensions $(20 \%, \mathrm{v} / \mathrm{v})$ at $-20^{\circ} \mathrm{C}$. Biomass for chemical and molecular systematic studies was obtained by cultivation in flasks of trypticase soy broth (Difco) $(\mathrm{pH} 7 \cdot 0)$ at $28^{\circ} \mathrm{C}$ for 1 week.

Extraction of genomic DNA and amplification of 23S rRNA and 16S rRNA genes were done as described by Xu et al. (2003). The product of amplification of the $23 \mathrm{~S}$ rRNA gene sequence of strain YIM $70056^{\mathrm{T}}$, comprising $380 \mathrm{bp}$, indicated that this strain is a high-G+C-DNA Grampositive bacterium, i.e. an actinobacterium (Stackebrandt et al., 1997; Yu et al., 2001). An almost-complete 16S rRNA 
gene sequence of strain YIM $70056^{\mathrm{T}}$, comprising $1466 \mathrm{bp}$, was obtained and compared with those of type strains within the genus Rhodococcus (downloaded from the GenBank/ EMBL/DDBJ database). Phylogenetic analysis was performed using the software packages PHYLIP (Felsenstein, 1993) and MEGA version 2.1 (Kumar et al., 2001) after multiple alignment of the data using CLUSTAL X (Thompson et al., 1997). Distances (using distance options according to the Kimura two-parameter model; Kimura, 1980, 1983) were calculated and clustering was performed with the neighbour-joining method (Saitou \& Nei, 1987). Bootstrap analysis (1000 resamplings) was used to evaluate the tree topology of the neighbour-joining data (Felsenstein, 1985).

The 16S rRNA gene sequence of strain YIM $70056^{\mathrm{T}}$ contained the signature nucleotides that are specific for the genus Rhodococcus (Goodfellow et al., 1998) and showed the highest similarity $(98.9 \%)$ to that of Rhodococcus fascians DSM $20669^{\mathrm{T}}$ (Fig. 1), but less than $97 \cdot 0 \%$ similarity to any other Rhodococcus species with validly published names. DNA-DNA hybridization experiments between strain YIM $70056^{\mathrm{T}}$ and the marker strain $R$. fascians DSM $20669^{\mathrm{T}}$ were performed using the optical renaturation method (De Ley et al., 1970; Huß et al., 1983; Jahnke, 1992). The hybridization value of the two strains was $40 \cdot 1 \%$. The G+C content of the DNA was determined to be $63.5 \mathrm{~mol} \%$ using the thermal denaturation $\left(T_{\mathrm{m}}\right)$ method (Marmur \& Doty, 1962).

The morphological properties of strain YIM $70056^{\mathrm{T}}$ were examined by using light microscopy (BH 2; Olympus) and electron microscopy (JEM-1010; JEOL). Cells were stained according to the classical Gram procedure after incubation for $24 \mathrm{~h}$ on ISP5 agar medium at $28^{\circ} \mathrm{C}$; their morphology was then checked. Strain YIM $70056^{\mathrm{T}}$ was Gram-positive, with hyphae that fragmented into short rods/coccobacilli. Colony colour was determined by comparison with colour

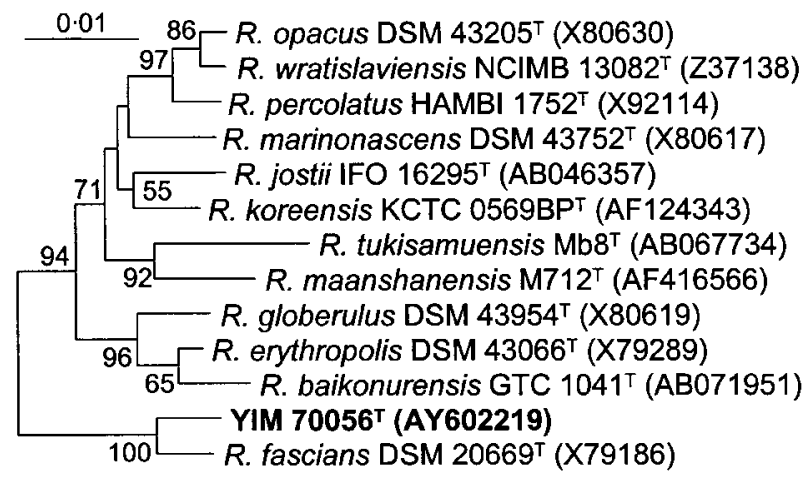

Fig. 1. Neighbour-joining tree showing the phylogenetic relationships among strain YIM $70056^{\top}$ and related strains, based on 16S rRNA gene sequences. Numbers on branch nodes are bootstrap values (percentages of 1000 replicates). Bar, $1 \mathrm{nt}$ substitution per $100 \mathrm{nt}$. An extended version of this tree is available as supplementary material in IJSEM Online. chips from the ISCC-NBS colour chart standard samples (Kelly, 1964); colonies were pale yellow to orange. The maximum diameter of colonies was approximately $0 \cdot 5$ $1.0 \mathrm{~mm}$ after 3 days growth.

All physiological and biochemical tests were performed at $28^{\circ} \mathrm{C}$. Carbon-source utilization tests, sugar fermentation analyses and qualitative enzyme tests were carried out using API ID 32E and API $50 \mathrm{CH}$ test kits (bioMérieux). Catalase activity was detected from the production of bubbles after the addition of a drop of $3 \% \mathrm{H}_{2} \mathrm{O}_{2}$. Oxidase activity was determined from the oxidation of $1 \% p$-aminodimethylaniline oxalate. Growth at various $\mathrm{NaCl}$ concentrations was investigated in ISP 5 broth: growth of strain YIM $70056^{\mathrm{T}}$ was observed in the presence of $0-10 \% \mathrm{NaCl}$.

The amino acid and sugar contents of cell walls were determined according to procedures described by Stanek \& Roberts (1974). Polar lipids were extracted, examined by two-dimensional TLC and identified using published procedures (Minnikin et al., 1984). Menaquinones were isolated using the methods of Minnikin et al. (1984) and separated by HPLC (Kroppenstedt, 1982). The cellular fatty acid composition was determined as described by Sasser (1990), using the Microbial Identification System (MIDI). Mycolic acids were extracted and analysed as described by Klatte et al. (1994a).

Strain YIM $70056^{\mathrm{T}}$ contained meso-LL-diaminopimelic acid as the diamino acid. Whole-cell hydrolysates were rich in arabinose and galactose (wall chemotype IV sensu Lechevalier \& Lechevalier, 1970a, b). The phospholipids contained phosphatidylcholine, diphosphatidylglycerol and phosphatidylinositol mannoside. The major menaquinone was MK- $8\left(\mathrm{H}_{2}\right)$. The fatty acid and mycolic acid profiles of strain YIM $70056^{\mathrm{T}}$ are described in detail in the species description.

The 16S rRNA gene sequence similarities between strain YIM $70056^{\mathrm{T}}$ and the type strains of species with validly published names were below $97.0 \%$, except in the case of $R$. fascians DSM $20669^{\mathrm{T}}$, which showed $98.9 \%$ similarity (Fig. 1); this indicates that strain YIM $70056^{\mathrm{T}}$ represents a different species with respect to Rhodococcus species apart from $R$. fascians DSM $20669^{\mathrm{T}}$. A full phylogenetic tree is available as a supplementary figure in IJSEM Online. The $16 \mathrm{~S}$ rRNA gene sequence of strain YIM $70056^{\mathrm{T}}$, containing the signature nucleotides that were specific to the $R$. erythropolis $16 \mathrm{~S}$ rDNA subclade, confirms the view that the tested strain should be classified in that subclade. This assignment is supported by chemotaxonomic data, including peptidoglycan type, cell-wall sugar, menaquinone and polar lipid compositions and fatty acid and mycolic acid profiles.

Most of the physiological characteristics of strain YIM $70056^{\mathrm{T}}$ are also consistent with those of $R$. fascians DSM $20669^{\mathrm{T}}$. However, strain YIM $70056^{\mathrm{T}}$ could utilize maltose, acetamide, lactose and $\mathrm{N}$-acetylglucosamine as sole carbon 
Table 1. Characteristics that distinguish strain $\mathrm{YIM} 70056^{\top}$ from the most closely related species of the genus Rhodococcus

Strains: 1, YIM $70056^{\mathrm{T}}$; 2, R. fascians DSM 20669 $;$;, Rhodococcus maanshanensis $\mathrm{M} 712^{\mathrm{T}}$; 4, Rhodococcus erythropolis DSM 43066 ${ }^{\mathrm{T}}$; 5,

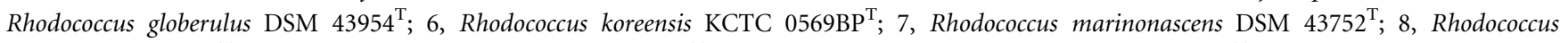
opacus DSM 43205 $5^{\mathrm{T}}$; 9, Rhodococcus percolatus HAMBI $1752^{\mathrm{T}}$; 10, Rhodococcus wratislaviensis NCIMB $13082^{\mathrm{T}}$; 11, Rhodococcus jostii IFO $16295^{\mathrm{T}} ; 12$, Rhodococcus tukisamuensis $\mathrm{Mb}^{\mathrm{T}} ; 13$, Rhodococcus baikonurensis GTC $1041^{\mathrm{T}}$. Data for all species except strain YIM $70056^{\mathrm{T}}$ are from previous studies (Helmke \& Weyland, 1984; Zhang et al., 2002; Klatte et al., 1994b; Briglia et al., 1996; Yoon et al., 2000; Goodfellow et al., 2002; Takeuchi et al., 2002; Matsuyama et al., 2003; Li et al., 2004). Characteristics are scored as follows: +, positive; W, weakly positive; -, negative; ND, undetermined.

\begin{tabular}{|c|c|c|c|c|c|c|c|c|c|c|c|c|c|}
\hline Characteristic & 1 & 2 & 3 & 4 & 5 & 6 & 7 & 8 & 9 & 10 & 11 & 12 & 13 \\
\hline $\begin{array}{l}\text { Morphogenetic } \\
\text { sequence }^{*}\end{array}$ & $\mathrm{H}-\mathrm{R}-\mathrm{C}$ & $\mathrm{H}-\mathrm{R}-\mathrm{C}$ & $\mathrm{R}-\mathrm{C}$ & EB-R-C & EB-R-C & EB-R-C & $\mathrm{H}-\mathrm{R}-\mathrm{C}$ & $\mathrm{H}-\mathrm{R}-\mathrm{C}$ & $\mathrm{H}-\mathrm{R}-\mathrm{C}$ & EB-R-C & $\mathrm{H}-\mathrm{R}-\mathrm{C}$ & $\mathrm{H}-\mathrm{R}-\mathrm{C}$ & ND \\
\hline Aesculin & + & - & + & + & + & - & + & - & - & + & ND & + & + \\
\hline Urea & - & + & + & + & + & + & - & + & + & + & - & - & + \\
\hline Arabitol & + & + & - & - & + & + & - & + & + & + & $\mathrm{ND}$ & - & - \\
\hline D-Cellobiose & - & - & - & - & - & - & - & + & - & - & ND & + & $\mathrm{ND}$ \\
\hline D-Galactose & + & + & + & - & - & + & - & + & + & + & - & + & - \\
\hline myo-Inositol & - & - & - & + & - & + & + & + & + & + & - & - & - \\
\hline D-Lactose & + & - & - & - & - & + & - & + & - & - & + & - & - \\
\hline D-Ribose & + & + & + & + & + & + & - & + & + & - & - & $\mathrm{W}$ & ND \\
\hline D-Sorbitol & + & + & - & + & + & + & $\mathrm{W}$ & + & + & + & - & - & $\mathrm{ND}$ \\
\hline D-Sucrose & + & + & + & + & + & + & - & + & + & + & - & + & ND \\
\hline D-Trehalose & + & + & $\mathrm{W}$ & + & + & + & - & + & + & + & - & & ND \\
\hline D-Xylose & + & + & - & - & + & + & $\mathrm{W}$ & - & + & - & + & - & - \\
\hline $\begin{array}{l}\text { Mycolic acid } \\
\text { (no. of carbons) }\end{array}$ & $44-52$ & $38-52$ & ND & $34-38$ & ND & $\mathrm{ND}$ & ND & $48-53$ & $46-54$ & $\mathrm{ND}$ & ND & $44-52$ & $32-42$ \\
\hline
\end{tabular}

${ }^{\star}$ Growth cycles: EB-R-C, elementary branching rod-coccus; H-R-C, hypha-rod-coccus; R-C, rod-coccus.

sources and could not hydrolyse starch, all of which distinguish it from R. fascians DSM $20669^{\mathrm{T}}$ (Table 1). Additionally, the fatty acid and mycolic acid profiles of strain YIM $70056^{\mathrm{T}}$ are distinguishable from those of $R$. fascians DSM $20669^{\mathrm{T}}$. The fatty acid profile is presented in the species description given below. In YIM $70056^{\mathrm{T}}$, the mycolic acids contain 44-52 carbon atoms, while those in $R$. fascians DSM $20669^{\mathrm{T}}$ contain 38-52 carbon atoms. The DNA-DNA relatedness $(40 \cdot 1 \%)$ between YIM $70056^{\mathrm{T}}$ and $R$. fascians DSM $20669^{\mathrm{T}}$ is below the $70 \%$ cut-off point recommended by Wayne et al. (1987) for the recognition of genomic species. This confirms that strain YIM $70056^{\mathrm{T}}$ represents a novel species of the genus Rhodococcus, for which we propose the name Rhodococcus yunnanensis sp. nov.

\section{Description of Rhodococcus yunnanensis sp. nov.}

Rhodococcus yunnanensis (yun.nan.en'sis. N.L. masc. adj. yunnanensis pertaining to Yunnan, a province of south-west China).
Gram-positive, aerobic, non-motile, catalase-positive, oxidase-negative and mesophilic actinobacterium with hyphae that fragment into short rods/coccobacilli. Grows well on almost all media tested, such as ISP2, TSA and peptone/yeast extract/glucose medium. Colonies are pale yellow to orange, smooth, opaque and $0.5-1.0 \mathrm{~mm}$ in diameter. Strain YIM $70056^{\mathrm{T}}$ is positive for lipase and alkaline phosphatase. It can hydrolyse Tweens 20, 40 and 80, while milk coagulation, nitrate reduction, $\beta$-glucuronidase, $\alpha$-galactosidase, $\beta$-galactosidase, $N$-acetylglucosaminidase, $\beta$-glucosidase, urease and gelatin liquefaction tests are negative. Temperature range for growth is $10-40{ }^{\circ} \mathrm{C}$, with an optimum temperature of $28-30{ }^{\circ} \mathrm{C}$. Optimal $\mathrm{pH}$ for growth is $7 \cdot 0-8 \cdot 0$. $\mathrm{NaCl}$ tolerance range is $0-10 \%$. Good growth occurs on almost all carbon sources tested, including glucose, D-ribose, acetamide, galactose, arabinose, lactose, mannose, mannitol, fructose, sucrose, arabitol, sorbitol, maltose and xylose, but acid is produced only from acetamide. It contains meso-LL-diaminopimelic acid, arabinose and galactose in whole-organism hydrolysates. 
Predominant phospholipids are phosphatidylcholine, diphosphatidylglycerol and phosphatidylinositol mannoside. The major menaquinone is $\mathrm{MK}-8\left(\mathrm{H}_{2}\right)$. The fatty acid profile is as follows: $\mathrm{C}_{16: 0}, 18 \cdot 3 \% ; \mathrm{C}_{18: 1} \omega 9 c, 11 \cdot 4 \%$; 10-methyl $\mathrm{C}_{18: 0}$ (tuberculostearic acid), $15.6 \% ; \mathrm{C}_{14: 0}$, $6 \cdot 3 \% ; \quad \mathrm{C}_{19: 0}, \quad 3 \cdot 2 \% ; \quad \mathrm{C}_{15: 0}, \quad 2 \cdot 8 \% ; \quad \mathrm{C}_{17: 1} \omega 8 c, \quad 2 \cdot 4 \%$; $\mathrm{C}_{15: 1} \omega 5 c, 2 \% ; \mathrm{C}_{20: 4}, 1.8 \% ; 10$-methyl $\mathrm{C}_{16: 0}, 1.6 \%$; $\mathrm{C}_{20: 0}, 1.3 \%$; and $\mathrm{C}_{17: 1} \omega 5 c, 1.2 \%$. The mycolic acids range from $\mathrm{C} 44$ to $\mathrm{C} 52: \mathrm{C} 48$ (26\%), C50 (20\%), C46 (13\%), C49 (12\%), C51 (9\%), C52 (9\%), C44 (4\%), C45 $(4 \%)$ and $\mathrm{C} 47(4 \%)$. The DNA $\mathrm{G}+\mathrm{C}$ content is $63 \cdot 5 \mathrm{~mol} \%$.

The type strain, strain YIM $70056^{\mathrm{T}}$ (=CCTCC AA $204007^{\mathrm{T}}=$ KCTC $\left.19021^{\mathrm{T}}=\mathrm{DSM} \quad 44837^{\mathrm{T}}\right)$, was isolated from a forest soil sample collected in Yunnan Province in south-west China.

\section{Acknowledgements}

This research was supported by the National Basic Research Program of China (project no. 2004CB719601), the National Natural Science Foundation of China (project no. 30270004), the Yunnan Provincial Natural Science Foundation (project no. 2004C0002Q) and the 21C Frontier Microbial Genomics and Application Center Program, Ministry of Science \& Technology (MG02-0101-002-1-0-0) and the International Cooperation R \& D Program, Ministry of Science \& Technology (M6-0203-00-0002), Korea.

\section{References}

Briglia, M., Rainey, F. A., Stackebrandt, E., Schraa, G. \& SalkinojaSalonen, M. S. (1996). Rhodococcus percolatus sp. nov., a bacterium degrading 2,4,6-trichlorophenol. Int J Syst Bacteriol 46, 23-30.

De Ley, J., Cattoir, H. \& Reynaerts, A. (1970). The quantitative measurement of DNA hybridization from renaturation rates. Eur J Biochem 12, 133-142.

Felsenstein, J. (1985). Confidence limits on phylogenies: an approach using the bootstrap. Evolution 39, 783-791.

Felsenstein, J. (1993). PHYLIP (phylogeny inference package), version 3.5c. Seattle: University of Washington.

Goodfellow, M., Alderson, G. \& Chun, J. (1998). Rhodococcal systematics: problems and developments. Antonie van Leeuwenhoek 74, 3-20.

Goodfellow, M., Chun, J., Stackebrandt, E. \& Kroppenstedt, R. M. (2002). Transfer of Tsukamurella wratislaviensis Goodfellow et al. 1995 to the genus Rhodococcus as Rhodococcus wratislaviensis comb. nov. Int J Syst Evol Microbiol 52, 749-755.

Helmke, E. \& Weyland, H. (1984). Rhodococcus marinonascens sp. nov., an actinomycete from the sea. Int J Syst Bacteriol 34, 127-138.

Holdeman, L. V. H., Cato, E. P. \& Moore, W. E. C. (1977). Anaerobe Laboratory Manual, 4th edn. Blacksburg, VA: Virginia Polytechnic and State University.

Huß, V. A. R., Festl, H. \& Schleifer, K.-H. (1983). Studies on the spectrophotometric determination of DNA hybridization from renaturation rates. Syst Appl Microbiol 4, 184-192.

Jahnke, K.-D. (1992). Basic computer program for evaluation of spectroscopic DNA renaturation data from GILFORD system 2600 spectrophotometer on a PC/XT/AT type personal computer. J Microbiol Methods 15, 61-73.
Kelly, K. L. (1964). Inter-Society Color Council - National Bureau of Standards Color-Name Charts Illustrated with Centroid Colors. Washington, DC: US Government Printing Office.

Kimura, M. (1980). A simple method for estimating evolutionary rates of base substitutions through comparative studies of nucleotide sequence. J Mol Evol 16, 111-120.

Kimura, M. (1983). The Neutral Theory of Molecular Evolution. Cambridge: Cambridge University Press.

Klatte, S., Kroppenstedt, R. M. \& Rainey, F. A. (1994a). Rhodococcus opacus sp. nov., an unusual nutritionally versatile Rhodococcusspecies. Syst Appl Microbiol 17, 355-360.

Klatte, S., Jahnke, K. D., Kroppenstedt, R. M., Rainey, F. \& Stackebrandt, E. (1994b). Rhodococcus luteus is a later subjective synonym of Rhodococcus fascians. Int J Syst Bacteriol 44, 627-630.

Kroppenstedt, R. M. (1982). Separation of bacterial menaquinones by HPLC using reverse phase (RP 18) and a silver loaded ion exchanger as stationary phases. J Liq Chromatogr 5, 2359-2387.

Kumar, S., Tamura, K., Jakobsen, I. B. \& Nei, M. (2001). MEGA2: Molecular Evolutionary Genetics Analysis software. Bioinformatics 17, 1244-1245.

Lechevalier, H. A. \& Lechevalier, M. P. (1970a). Critical evaluation of the genera of aerobic actinomycetes. In The Actinomycetes, pp. 393-405. Edited by H. Prauser. Jena: Gustav Fischer.

Lechevalier, M. P. \& Lechevalier, H. A. (1970b). Chemical composition as a criterion in the classification of aerobic actinomycetes. Int J Syst Bacteriol 20, 435-443.

Li, Y., Kawamura, Y., Fujiwara, N., Naka, T., Liu, H. S., Huang, X. X., Kobayashi, K. \& Ezaki, T. (2004). Rothia aeria sp. nov., Rhodococcus baikonurensis sp. nov. and Arthrobacter russicus sp. nov., isolated from air in the Russian space laboratory Mir. Int J Syst Evol Microbiol 54, 827-835.

Marmur, J. \& Doty, P. (1962). Determination of base composition of deoxyribonucleic acid from its denaturation temperature. J Mol Biol 5, 109-118.

Matsuyama, H., Yumoto, I., Kudo, T. \& Shida, O. (2003). Rhodococcus tukisamuensis sp. nov., isolated from soil. Int J Syst Evol Microbiol 53, 1333-1337.

McMinn, E. J., Alderson, G., Dodson, H. I., Goodfellow, M. \& Ward, A. C. (2000). Genomic and phenomic differentiation of Rhodococcus equi and related strains. Antonie van Leeuwenhoek 78, 331-340.

Minnikin, D. E., O’Donnell, A. G., Goodfellow, M., Alderson, G., Athalye, M., Schaal, A. \& Parlett, J. H. (1984). An integrated procedure for the extraction of isoprenoid quinones and polar lipids. J Microbiol Methods 2, 233-241.

Saitou, N. \& Nei, M. (1987). The neighbor-joining method: a new method for reconstructing phylogenetic trees. Mol Biol Evol 4, 406-425.

Sasser, M. (1990). Identification of bacteria by gas chromatography of cellular fatty acids. USFCC Newsl 20, 16.

Shirling, E. B. \& Gottlieb, D. (1966). Methods for characterization of Streptomyces species. Int J Syst Bacteriol 16, 313-340.

Stackebrandt, E., Rainey, F. A. \& Ward-Rainey, N. L. (1997). Proposal for a new hierarchic classification system, Actinobacteria classis nov. Int J Syst Bacteriol 47, 479-491.

Stanek, J. L. \& Roberts, G. D. (1974). Simplified approach to identification of aerobic actinomycetes by thin layer chromatography. Appl Microbiol 28, 226-231.

Takeuchi, M., Hatano, K., Sedlácek, I. \& Pácová, Z. (2002). Rhodococcus jostii sp. nov., isolated from a medieval grave. Int J Syst Evol Microbiol 52, 409-413. 
Thompson, J. D., Gibson, T. J., Plewniak, F., Jeanmougin, F. \& Higgins, D. G. (1997). The CLUSTAL X windows interface: flexible strategies for multiple sequence alignment aided by quality analysis tools. Nucleic Acids Res 24, 4876-4882.

Wayne, L. G., Brenner, D. J., Colwell, R. R. \& 9 other authors (1987). International Committee on Systematic Bacteriology. Report of the ad hoc committee on reconciliation of approaches to bacterial systematics. Int J Syst Bacteriol 37, 463-464.

Xu, P., Li, W. J., Xu, L. H. \& Jiang, C. L. (2003). A microwave-based method for genomic DNA extraction from actinomycetes. Microbiology 30, 73-75 (in Chinese).
Yoon, J.-H., Cho, Y.-G., Kang, S.-S., Kim, S. B., Lee, S. T. \& Park, Y.-H. (2000). Rhodococcus koreensis sp. nov., a 2,4-dinitrophenoldegrading bacterium. Int J Syst Evol Microbiol 50, 1193-1201.

Yu, L. Y., Li, Q. P. \& Yao, T. J. (2001). Comparison of two methods for identifying Actinobacteria. Chin J Antibiot 26, 10-14.

Zhang, J. L., Zhang, Y. M., Xiao, C. S., Liu, Z. H. \& Goodfellow, M. (2002). Rhodococcus maanshanensis sp. nov., a novel actinomycete from soil. Int J Syst Evol Microbiol 52, 2121-2126.

Zopf, W. (1891). Über Ausscheidung von Fettfarbstoffen (Lipochromen) seitens gewisser Spaltpilze. Ber Dtsch Bot Ges 9, 22-28 (in German). 